\title{
Prevalence of Asthma symptoms and risk factors in adolescents
}

\author{
Elisangela Vilar de Assis ${ }^{1,2}$, Milana D. R. Santana1, Ankilma do \\ N. A. Feitosa ${ }^{1,2}$, Milena N. Alves de Sousa ${ }^{3}$, Ubiraídys de A. \\ Isidório ${ }^{1,2}$, Vitor E. Valenti ${ }^{4}$, Fernando Luiz Affonso Fonseca ${ }^{1}$ \\ ${ }^{1}$ Faculdade de Medicina do ABC, Santo André, São Paulo. \\ ${ }^{2}$ Faculdade Santa Maria, Cajazeiras, Paraíba. \\ ${ }^{3}$ Faculdades Integradas de Patos - FIP, Patos, Paraíba. \\ ${ }^{4}$ Programa de Pós-Graduação em Fisioterapia, Faculdade de Ciências e Tecnologia, \\ UNESP, Presidente Prudente, SP, Brasil.
}

Corresponding author: ely.vilar@hotmail.com

Manuscript received: May 2018

Manuscript accepted: December 2018

Version of record online: April 2019

\begin{abstract}
Introduction: Asthma is a chronic disease of the airways, which is increasing its prevalence among teenagers recently. The trigger-related factors are numerous, including environmental factors, genetic, food among others.
\end{abstract}

Objective: Investigate the prevalence of asthma symptoms and possible risk factors in adolescents.

Methods: This is a cross-sectional, descriptive and quantitative study conducted in 104 adolescents aged between 13 to 14 years old of both sexes from four educational institutions: three private and one public. Participants answered two questionnaires: one on risk factors for allergic diseases (EISL) and the other on asthma symptoms (ISAAC asthma module).

Results: 104 adolescents answered the questionnaire: $54.8 \%$ girls and $45.2 \%$ boys. Male subjects had the most active asthma $(64 \%)$ than female $(20 \%)(p=0.01)$ and also had more physician-diagnosed asthma $(34.4 \%)$ than girls $(6.1 \%)(p=0.04)$, more wheezing after exercise $(34.4 \% ; 12.1 \%)(p=0.03)$. Regarding the association between the symptoms and the risk factors we observed a statistically significant relationship between the presence of wheezing and hospitalization for public schools girls $(p=0.05)$.

Conclusion: There is a higher prevalence of asthma symptoms in males than in females unlike other studies was observed.

Keywords: epidemiology, allergic disease, autonomic dysfunction, risk factors, teenager.

\section{Why this study was made?}

The study was developed because the prevalence of asthma symptoms are high among adolescents and over the years other risk factors have been associated with its exacerbation.

\section{What researchers have done and found?}

The researchers investigated possible risk factors related to the onset of asthma symptoms in adolescents and noted that male volunteers had more active asthma than volunteers, also had more asthma diagnosed and wheezing after exercise. With regard to the association between symptoms and risk factors, a statistically significant relationship was observed between the presence of wheezing and hospitalizations for girls from public schools.

\section{What the results mean?}

Although the female gender suffered from hormonal changes during adolescence, it was observed that asthma symptoms were more prevalent in males. It is also worth noting that the volunteers from the public school system showed an association of risk factors with hospitalization, suggesting that the socioeconomic factor may have a greater influence on the prevalence of asthma symptoms than hormonal changes. 


\section{INTRODUCTION}

Asthma is a chronic disease of the airways that can impose substantial morbidity for the individual and cost for the health care system. Some parameters that are associated with triggering the condition are known, such as environmental factors, difference between the sexes, and its diagnosis ${ }^{1}$; however, it is still considered a multifaceted disease ${ }^{2}$. There is a gap in the etiology of asthma in adolescents due to the lack of longitudinal studies $^{1}$. Asthma is also associated with an imbalance of the autonomic nervous system, which may be due to a parasympathetic hyper function or to an imbalance between the sympathetic and parasympathetic nervous systems $^{3}$.

This disease is responsible for an average of 200.000 hospitalizations per year in Brazil, representing the fourth largest cause of hospitalization for the Unified Health System. In 2009 alone, these hospitalizations accounted for an expense of $\mathrm{R} \$ 103$ million. An international survey pointed to a prevalence of asthma symptoms of $21 \%$ among adolescents of 13 and 14 years of age in Brazil, resulting in approximately 2.2 million visits to the doctor per year ${ }^{4}$.

Worldwide, asthma affects 300 million people and this is estimated to increase by more than 100 million by 2025 . On average $5-10 \%$ of the world population has asthma; however, $1 / 3$ are under the age of 18. Symptoms of half of all asthma cases appear before the age of 5, for those over 40 year of age this percentage drops to $25 \%{ }^{5}$. Whatever the severity of asthma, it still causes physical, psychological and social impairment, with restrictions in quality of life when compared to individuals without asthma ${ }^{6}$.

Its emergence has a strong association with genetic interactions and environmental exposure to allergens and irritants, among other specific factors. Delayed treatment due to failure to recognize disease severity or reliance on medications has contributed to increased mortality. During childhood, the highest prevalence occurs among boys, in adolescence it is among girls. This fact has been attributed to hormonal factors ${ }^{4}$.

Despite the large amount of research on its pathophysiology and forms of treatment, asthma has been showing an increase in prevalence, morbidity and mortality in several countries in recent decades. Several theories have been put forward to explain the factors related to asthma, this includes the interaction between genetic and environmental factors, which has also been implicated in other allergic diseases. Other determinants have also been associated with the prevalence of asthma such as pollution, dietary changes, allergen exposure and improved hygiene ${ }^{5}$.

Faced with the increase in the prevalence of asthma, it is necessary to know which risk factors may contribute to the appearance and/or worsening of symptoms. From this knowledge, educational measures aimed at preventing crises can be disseminated among parents and adolescents to minimize the stress of managing the condition, as well as reducing public expenditure for preventable hospitalizations. Therefore, the objective of this study was to analyze the prevalence of asthma symptoms and associated risk factors in adolescents.

\section{METHODS}

This was a cross-sectional, descriptive study with a quantitative approach carried out in 3 private schools in the city of Cajazeiras, Paraíba, Brazil and a public school in the city of Juazeiro do Norte, Ceará, Brazil. Collection of data took place from August 2013 to October 2014. The participants were selected on the basis of convenience and access, 124 students were evaluated; however, 20 questionnaires were excluded because they were incomplete.

Included in the study were well-nourished adolescents of both sexes, aged 13 - 14 years; those with cardiac and/or neurological disease were excluded. Two questionnaires were used: a questionnaire adapted from the International Study of Wheezing in Infants (EISL), consisting of objective questions translated from Spanish to Portuguese to determine the risk factors for allergic diseases, and validated in Brazil by Chong Neto et $a l^{7}$ and the International Study of Asthma and Allergies in Childhood (ISAAC) questionnaire validated by Solé et al. ${ }^{8}$, which provided a guide to determine the presence of "active asthma", "severe asthma" and an "asthma diagnosis" according to the questionnaire responses.

The research was approved by the Research Ethics Committee of the ABC Medical School under protocol $n^{\circ} 361.497$, which contemplated respect for the guidelines and norms of Resolution 466/12 regarding research involving human beings by the National Health Council. Visits were made to the pre-selected institutions to identify the adolescent participants, who were then invited to take part in the study. Terms of consent were signed by the participants, and their parents or guardians signed an informed consent form. On receipt of the duly signed terms, the questionnaires were given to the students and anthropometric evaluations were performed. The research took place during the morning in the classroom, from 8 am to 11 am.

A database was built in the SPSS Statistics for Windows program, Version 21 (IBM Corp., Armonk, NY, USA). Descriptive measures of frequency and percentages presented in contingency tables were used. As an inferential test, bivariate logistic regressions were performed for some data, because in some cases the tables presented frequencies equal to zero. A significance level of $95 \%$ was adopted; that is, $\mathrm{p}<0.05$.

\section{RESULTS}

The group of participants was divided by public and private school and by gender. Among the participants, 40 responded negatively to the presence of active asthma, diagnostic asthma and severe asthma (Table 1). 
Table 1: Bio-demographic data of students according to school type.

\begin{tabular}{llcccc}
\hline & & \multicolumn{2}{c}{ Public } & \multicolumn{2}{c}{ Private } \\
\hline \multirow{3}{*}{ Sex } & $\mathrm{n}$ & $\%$ & $\mathrm{n}$ & $\%$ & \\
\multirow{3}{*}{ Age } & Female & 33 & 50.8 & 24 & 61.5 \\
& Male & 32 & 49.2 & 15 & 38.5 \\
\multirow{3}{*}{ Diseases } & 13 years & 34 & 52.3 & 24 & 61.5 \\
& 14 years & 31 & 47.7 & 15 & 38.5 \\
& Asthma & 6 & 12.24 & 2 & 8 \\
& Asthma, rhinitis & 8 & 16.32 & 6 & 24 \\
& Asthma, rhinitis eczema & 5 & 10.20 & 2 & 8 \\
& Eczema & 2 & 4.08 & 3 & 12 \\
& Rhinitis & 24 & 48.96 & 7 & 28 \\
& Rhinitis, eczema & 4 & 8.16 & 5 & 20 \\
\hline
\end{tabular}

Table 2 shows the associations for the public school. Males had more active asthma (64\%) than females $(20 \% ; \mathrm{p}=0.01)$. Men also had more asthma diagnosed $(34.4 \%)$ than women $(6.1 \% ; \mathrm{p}=0.04)$, and had more wheezing after exercise $(34.4 \%$ and $12.1 \%$, respectively; $\mathrm{p}=0.03)$.

The questions regarding active, severe and diagnosed asthma were associated with risk factors for allergic diseases. Among the associations, only the relation between the presence of wheezing and hospitalization for women from public schools presented a statistically significant result. The results showed that women with wheezing were 22 times more likely to be hospitalized for bronchitis ( $p=0.05$; Table 3$)$.

Table 2: Asthma symptoms in students according to school and sex.

\begin{tabular}{|c|c|c|c|c|c|}
\hline & & \multicolumn{2}{|c|}{ Public } & \multicolumn{2}{|c|}{ Private } \\
\hline & & $\begin{array}{c}\text { Female } \\
\text { n (\%) }\end{array}$ & $\begin{array}{l}\text { Male } \\
\text { n (\%) }\end{array}$ & $\begin{array}{c}\text { Female } \\
\text { n (\%) }\end{array}$ & $\begin{array}{l}\text { Male } \\
\text { n (\%) }\end{array}$ \\
\hline \multirow{3}{*}{$\begin{array}{l}\text { Have you ever had wheezing } \\
\text { (wheezing in your chest)? }\end{array}$} & No & $19(57.6)$ & $18(56.3)$ & $14(58.3)$ & $9(60)$ \\
\hline & Yes & $14(42.4)$ & $14(43.8)$ & $10(41.7)$ & $6(40)$ \\
\hline & $p$ & \multicolumn{2}{|c|}{0.91} & \multicolumn{2}{|c|}{0.92} \\
\hline \multirow{3}{*}{$\begin{array}{l}\text { In the last } 12 \text { (twelve) months you } \\
\text { had wheezing (wheezing in the } \\
\text { chest)? }\end{array}$} & No & $12(80)$ & $5(35.7)$ & $6(60)$ & $4(66.7)$ \\
\hline & Yes & $3(20)$ & $9(64.3)$ & $4(40)$ & $2(33.3)$ \\
\hline & $\mathrm{p}$ & \multicolumn{2}{|c|}{$0.01^{*}$} & \multicolumn{2}{|c|}{$0.79^{*}$} \\
\hline \multirow{5}{*}{$\begin{array}{l}\text { In the last } 12 \text { (twelve) months how } \\
\text { many wheezing crises (wheezing in } \\
\text { the chest) have you had? }\end{array}$} & Non & $9(69.2)$ & $4(28.6 \%)$ & $3(33.3)$ & $1(16.7)$ \\
\hline & 1 to 3 & $4(30.8)$ & $8(57.1)$ & $4(44.4)$ & $5(83.3)$ \\
\hline & 4 to 12 & 0.0 & $2(14.3)$ & $2(22.2)$ & 0.0 \\
\hline & More than 12 & 0.0 & 0.0 & 0.0 & 0.0 \\
\hline & $p$ & \multicolumn{2}{|c|}{0.07} & \multicolumn{2}{|c|}{0.27} \\
\hline \multirow{4}{*}{$\begin{array}{l}\text { In the last } 12 \text { (twelve) months how } \\
\text { often have you had your sleep } \\
\text { disturbed by wheezing in the chest? }\end{array}$} & Never & $11(84.6)$ & $8(57.1)$ & 7 (77.8) & $6(100)$ \\
\hline & $\begin{array}{l}\text { More than } \\
\text { one time }\end{array}$ & $2(15.4)$ & $3(21.4)$ & $2(22.2)$ & 0.0 \\
\hline & $\begin{array}{l}\text { One time or } \\
\text { more }\end{array}$ & 0.0 & $3(21.4)$ & 0.0 & 0.0 \\
\hline & $p$ & \multicolumn{2}{|c|}{0.16} & \multicolumn{2}{|c|}{0.21} \\
\hline
\end{tabular}


continuation - Table 2: Asthma symptoms in students according to school and sex.

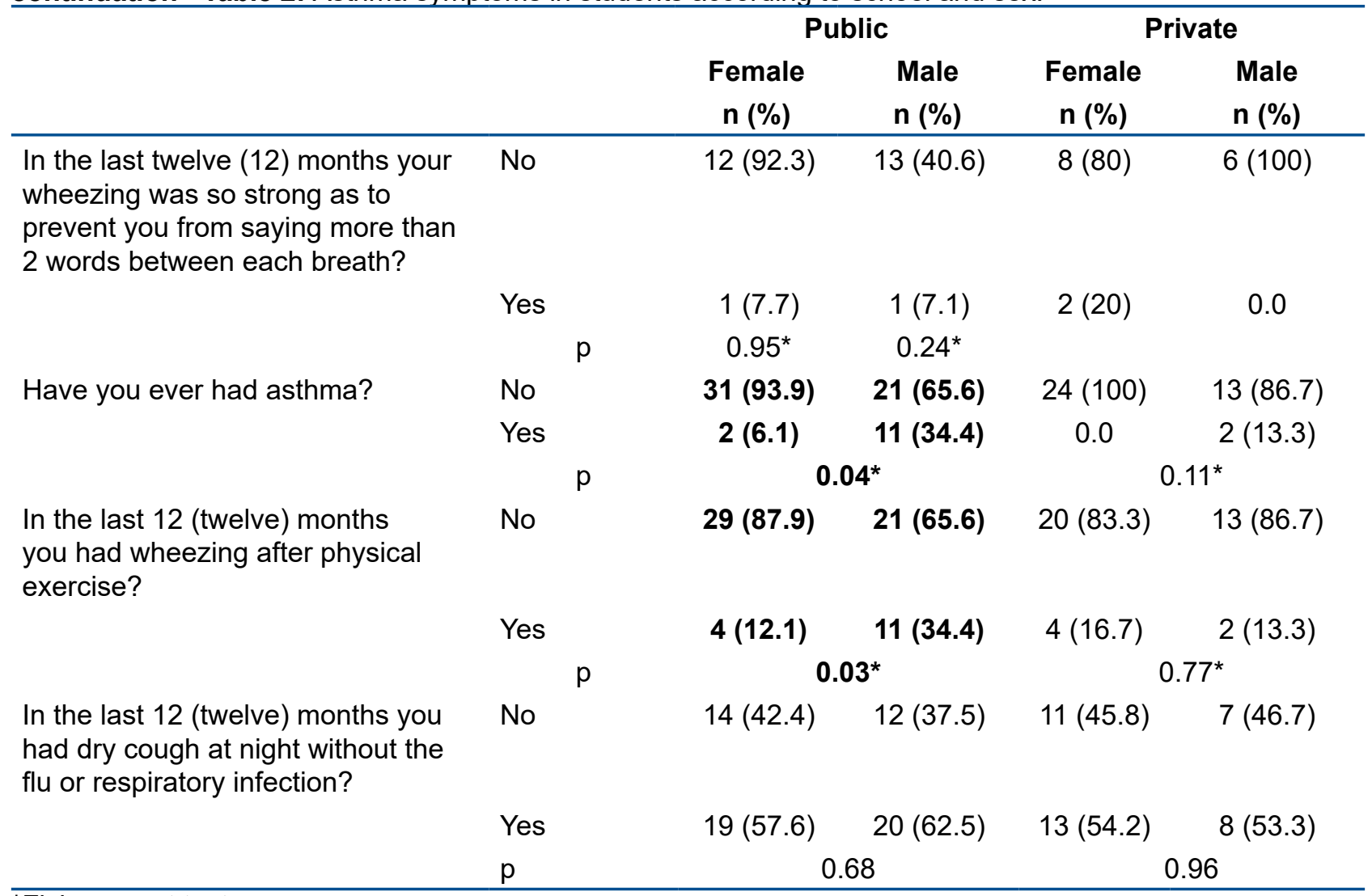

${ }^{*}$ Fisher exact test

Table 3: Association between wheezing in the chest and risk factors for asthma in students according to school and sex.

\begin{tabular}{|c|c|c|c|c|c|c|c|}
\hline \multirow[t]{2}{*}{$\begin{array}{l}\text { Risk factors } \\
\text { for asthma }\end{array}$} & & & & \multicolumn{2}{|c|}{$\begin{array}{l}\text { Wheezing episodes in the } \\
\text { last } 12 \text { (twelve) months }\end{array}$} & \multirow[t]{2}{*}{$\mathbf{p}$} & \multirow[t]{2}{*}{ OR (CI 95\%) } \\
\hline & & & & No & Yes & & \\
\hline \multirow{5}{*}{ Public } & & & & $\mathrm{n}(\%)$ & $n(\%)$ & & \\
\hline & \multirow[t]{2}{*}{ Female } & \multirow{2}{*}{$\begin{array}{l}\text { Have you ever been } \\
\text { hospitalized for } \\
\text { bronchitis? }\end{array}$} & $\mathrm{No}^{*}$ & $11(91.7)$ & $1(33.3)$ & 0.05 & $22.00(1.0-515.9)$ \\
\hline & & & Yes & $1(8.3)$ & $2(66.7)$ & & \\
\hline & \multirow[t]{2}{*}{ Male } & \multirow{2}{*}{$\begin{array}{l}\text { Have you ever been } \\
\text { hospitalized for } \\
\text { bronchitis? }\end{array}$} & $\mathrm{No}^{*}$ & $3(60.0)$ & $7(77.8)$ & 0.48 & $0.42(0.04-4.64)$ \\
\hline & & & Yes & $2(40)$ & $2(22.2)$ & & \\
\hline \multirow{4}{*}{ Private } & \multirow[t]{2}{*}{ Female } & \multirow{2}{*}{$\begin{array}{l}\text { Have you ever been } \\
\text { hospitalized for } \\
\text { bronchitis? }\end{array}$} & $\mathrm{No}^{*}$ & $6(100)$ & $4(100)$ & $* *$ & $* *$ \\
\hline & & & Yes & $0(0.0)$ & $0(0.0)$ & & \\
\hline & \multirow[t]{2}{*}{ Male } & \multirow{2}{*}{$\begin{array}{l}\text { Have you ever been } \\
\text { hospitalized for } \\
\text { bronchitis? }\end{array}$} & $\mathrm{No}^{*}$ & $3(750)$ & $2(1000)$ & ** & ** \\
\hline & & & Yes & $1(25)$ & $0(00)$ & & \\
\hline
\end{tabular}

${ }^{*}$ Reference value; ${ }^{* *}$ Insufficient percentage for inferential calculation.

Regarding the symptoms of asthma and other risk factors, no statistically significant results were observed; however, some trends were noted. The association between active asthma and the presence of carpet at home was examined according to the type of school. Public schools (boys $7 / 58.3 \%$ and girls $5 / 100 \%$ ) had a higher frequency of students with carpet at home who had wheezing than those from private schools (boys $3 / 75 \%$ and girls $2 / 50 \%$ ).

Concerning the association between severe asthma and passive smoking (family member at home who smoked), it was evident that public school students with severe wheezing had family members who smoked in the home. As for association between severe asthma and pets and severe asthma and atmospheric pollution near home, strong wheezers had a pet and lived in areas where the air was polluted, regardless of the school.

The majority of male students from public and private schools who have diagnosed asthma had carpet at home, respectively, yes $-16 / 76.2 \%$ and non-5/23.8\%; and yes $-9 / 69.2 \%$ and no $-4 / 30.8 \%$.

Concerning issues of heredity, it could be seen that most girls from public schools and boys and girls in private schools who had active asthma also had a relative with allergic rhinitis. Even so, there was no evidence of 
an association between active and family asthma with allergic dermatitis; however, with severe asthma there was a correlation for public school students.

\section{DISCUSSION}

The results of this study indicated a greater frequency of asthma symptoms among public school participants, especially boys. Socioeconomically disadvantaged participants presented with a higher prevalence of asthma symptoms and major crises ${ }^{4}$. This was consistent with Britto et al. ${ }^{9}$, who found that poverty could contribute to the onset, exacerbation and handling of asthma. Regarding etiology, this aspect is contrary to the hygiene theory, which argues that less favored people are exposed to more microbial agents and, therefore, less susceptible to developing the disease. By contrast, Solé $e t$ $a l .{ }^{10}$ reported that prevalence of asthma and its symptoms vary and are independent of socioeconomic level.

The ISAAC, which allowed the assessment of the prevalence of asthma internationally, showed that worldwide prevalence of asthma among adolescents (13 14 years) was $13.7 \%$, with a range of $1.5-32.6 \%$. In Latin America, the prevalence of active asthma was $6.6-27 \%$ in adolescents, with the highest prevalence values observed in centers close to the equator. Throughout the world, the prevalence was $13.8 \%$, ranging from $1.6 \%$ in India to $36.7 \%$ in Scotland 5 . In this approach, the prevalence of active asthma was much higher for men (64\%) than for women $(20 \%)$ and for general national and international statistics.

The studies carried out in Phases I and III of the ISAAC show a trend towards stabilization and even a decrease in the prevalence of asthma in adolescents in some localities. However, for the regions of Africa, India, Latin America, Northern Europe and Eastern Europe the expectation is for an increase ${ }^{11}$. In the study by Jucá et $a l .{ }^{11}$, the prevalence of active asthma was $19.1 \%$. In other locations in Brazil, results from the ISAAC Phase III study showed active asthma rates varying from $11.8 \%$ in Nova Iguaçu (Rio de Janeiro) to $30.5 \%$ in Vitória da Conquista, Bahia, Brazil.

Jucá et al. ${ }^{11}$, proposed some explanations for the prevalence variation found in several studies, such as urbanization, westernization and population density growth, and the diversity of environmental factors ${ }^{3}$.

In childhood, the prevalence of asthma appears to be higher among boys, possibly due to the smaller diameter and greater tone of the airway 12, in addition to elevated levels of immunoglobulin $\mathrm{E}$ ( $\mathrm{IgE}$ ). This gender difference is reversed in adolescence, possibly due to hormonal factors in girls and to the fact that symptoms are overestimated by this group 5 . By contrast in our study, the highest prevalence of asthma symptoms was observed among adolescent boys.

The question of "wheezing in the last 12 months", because it limits time and is independent of the month in which the questionnaire was answered, represents a question of sensitivity and specificity in cases of asthma ${ }^{8}$. In the present study, 57.7\% answered "no" to this question against $42.3 \%$ of the participants who answered "yes". The importance of wheezing was evident from the association we found between the presence of wheezing and hospitalization in girls of public schools. In children, risk factors associated with hospitalization are related to inadequate treatment, lack of follow-up during treatment, frequent exacerbations, age $<5$ years and low socioeconomic status ${ }^{13}$.

Although no statistically significant findings were found regarding asthma symptoms associated with secondhand smoke, domestic animals and air pollution, some studies suggest the existence of such relationships. Passive smoking has been reported as contributing to the increased prevalence of wheezing and asthma especially in early childhood, with an odds ratio of $1.2-1.35$.

In a longitudinal study by Lawson et al. ${ }^{1}$ with 12 - 18 year old Canadian adolescents, a higher incidence of asthma was observed among girls compared to boys. In addition, there was a greater chance of reporting a new diagnosis of asthma in those who were exposed to passive smoke, and adolescents from rural areas were less likely to present a diagnosis of asthma; however, these relationships were not statistically significant.

Pets represent a source of allergens, though exposure, development of sensitization and asthma symptoms are complex relationships. Some aspects such as the date of the arrival of the pet in the domestic environment, age at exposure, number of animals, genetic predisposition and family history of atopy may contribute to the triggering of the disease ${ }^{11}$. There is evidence of an association between the onset of asthma in children and whether they have a mother, father or sibling with asthma $^{14}$.

The triggering factors for asthma and other allergic diseases include air pollution and various household activities. The type of diet in early childhood also plays a key role. The complexity of the interaction between these factors has generated inconsistent results in different regions of the world ${ }^{15}$. In a study conducted in Brazil, the authors concluded that the prevalence of asthma was related to air pollution, in the same way as in the Netherlands ${ }^{16}$.

Genetic factors, have not as yet explained the significant differences in the prevalence of allergic diseases; therefore, environmental factors when associated have shown a strong influence. Among these environmental factors are pollution, nutrition, exposure to allergens, socioeconomic level, and family size. However, there is no evidence to associate these factors with atopic phenotypes in epidemiological studies ${ }^{17}$.

Among allergic diseases, asthma, rhinitis and eczema have a strong correlation. Population studies estimate that $38 \%$ of patients with allergic rhinitis have asthma and $78 \%$ of asthmatics have associated rhinitis. Adults who have a family history of asthma and rhinitis have a 2 - 6-fold higher risk of developing rhinitis and a 3 - 4 times higher risk for asthma ${ }^{18}$.

Asthma has been found in 25 - 50\% of patients with rhinitis. Several studies have reported that nasal symptoms occur in $28-78 \%$ of asthmatics aged $13-14$ years ${ }^{19}$. Rheumatoid arthritis (RA) and asthma have a common pathophysiological mechanism, since the treatment of RA reduces the incidence and severity of asthma. Atopic 
dermatitis, even with a good prognosis, is also associated with the onset of signs and symptoms of RA and asthma ${ }^{20}$.

During this research, some factors contributed indirectly to a bias in the selection of schools, such as permission to carry out the data collection. The school agenda was also an important factor in the size of the sample, as it resulted in loss of participants during the application of the questionnaires, with the students having extra class activities, testing, the Olympics, school games and even a strike in the public schools.

\section{CONCLUSION}

In conclusion, there was a higher frequency of adolescent boys with active asthma, diagnosis asthma and wheezing after exercise. On the other hand, the public school girls presented with a higher risk of hospitalization in the presence of wheezing. The other risk factors did not present statistically significant associations with asthma symptoms.

\section{REFERENCES}

1. Lawson JA, Janssen I, Bruner MW, Hossain A, Pickett W. Asthma incidence and risk factors in a national longitudinal sample of adolescent Canadians: a prospective cohort study. BMC Pulmonary Med. 2014;14:51. DOI: https://dx.doi.org/10.1186/1471-2466-14-51

2. Carmo TA, Andrad SM, Cerci Neto A. Avaliação de um programa de controle da asma em unidades de saúde da família. Cad Saúde Pública. 2012;27(1):162-72. DOI: http://dx.doi.org/10.1590/S0102-311X2011000100017

3. Emin O, Esra G, Ufuk E, Demiric A, Ayhan S, Rusen DM. Autonomic dysfunction and clinical severity of disease in children withallergic rhinitis. Int J Pediatr Otorhinolaryngol. 2012;76(8):1196-200. DOI: http://dx.doi.org/10.1016/j.ijporl.2012.05.005

4. Castro GC, Sousa LKC, Vera PVS, Lima LHO, Oliveira EAR, Lima RFS, et al. Sintomas e fatores de risco para asma entre escolares Piauienses. Acta Paul Enferm. 2012;25(6):926-32. DOI: http://dx.doi.org/10.1590/S0103-21002012000600016

5. Lima WL, Lima EVNCL, Costa MRSR, Santos AM, Silva AAM, Costa ES. Asma e fatores associados em adolescentes de 13 e 14 anos em São Luís, Maranhão, Brasil. Cad Saúde Pública. 2012;28(6):1046-56. DOI: http://dx.doi.org/10.1590/S0102-311X2012000600004

6. Nogueira KT, Silva JRL, Lopes CS. Qualidade de vida em adolescentes asmáticos: avaliação da gravidade da asma, co-morbidade e estilo de vida. J Pediatr. 2009;85(6):523-30.

DOI: http://dx.doi.org/10.1590/S0021-75572009000600009

7. Chong Neto HJ, Rosário NA, Grupo EISL Curitiba (Estudio Internacional de Sibilanciasen Lactantes). Fatores de risco para sibilância no primeiro ano de vida. J Pediatr. 2008;84(6):495-502. DOI: http://dx.doi.org/10.1590/S0021-75572008000700005

8. Sole D, Vana AT, Yamada E, Rizzo M, Naspitz CK. International Study os Asthma and Allergies in Childhood (ISAAC) written questionnaire: validation of the asthma component among Brazilian children. J Investig Allergol Clin Immunol. 1998;8(6):376-82.

9. Britto MCA, Freire EFC, Bezerra PGM, Brito RCCM, Rego JC. Baixa renda como fator de proteção contra asma em crianças e adolescentes usuários do Sistema Único de Saúde. J Bras Pneumol. 2008;34(5):251-5. DOI: http://dx.doi.org/10.1590/S1806-37132008000500002

10. Solé D, Camelo-Nunes IC, Wandalsen GF, Mallozi MC, Naspitz CK; Brazilian ISAAC's Group. Is the prevalence of asthma and related symptoms among Brazilian children related to socioeconomic status? J Asthma. 2008;45(1):19-25. DOI: http://dx.doi.org/10.1080/02770900701496056

11. Jucá SCBMP, Takano OA, Moraes LSL, Guimarães LV. Prevalência e fatores de risco para asma em adolescentes de 13 a 14 anos do Município de Cuiabá, Mato Grosso, Brasil. Cad Saúde Pública. 2012;28(4):689-97. DOI: http://dx.doi.org/10.1590/S0102-311X2012000400008

12. Breda D, Freitas PF, Pizzichini E, Agostinho FR, Pizzichini MMM. Prevalência de sintomas de asma e fatores de risco associados em adolescentes escolares de 13 e 14 anos dos municípios de Tubarão e Capivari de Baixo, Santa Catarina, Brasil. Cad Saúde Pública. 2009; 25(11):2497-2506. DOI: http://dx.doi.org/10.1590/S0102-311X2009001100019

13. Brandão HV, Cruz CS, Guimarães A, Camargos PAM, Cruz AA. Fatores preditores de hospitalização por asma em crianças e adolescentes participantes de um programa de controle da asma. J Bras Pneumol. 2010;36(6):700-6. DOI: http://dx.doi.org/10.1590/S1806-37132010000600006

14. Kumar S, Babbar R, Varshney VP, Daga MK, Dalvi VS. A study of autonomic nervous system status in children of asthmatic parents. Indian J Physiol Pharmacol. 2012;56(1):74-9.

15. Pegas PN, Alves CA, Scotto MG, Evtyugina MG, Pio CA, Freitas MC. Factores de risco e prevalência de asma e rinite em crianças em idade escolar em Lisboa. Rev Port Pneumol. 2011;17(3):109-16. DOI: https://dx.doi.org/10.1016/j.rppneu.2011.01.004 
16. Azalim SP, Camargos P, Alves AL, Senna MIB, Sakurai E, Keller WS. Exposure to environmental factors and relationship to allergic rhinitis and/or asthma. Ann Agric Environ Med. 2014;21(1):59-63.

17. Ferraz E, Garcia CA, Bettiol H, Caldeira RD, Cardoso VC, Arruda LK, et al. Atopy risk factors at birth and in adulthood. J Pediatr. 2011;87(4):336-42. DOI: https://dx.doi.org/10.2223/JPED.2114

18. Camelo-Nunes IC, Solé D. Rinite alérgica: indicadores de qualidade de vida. J Bras Pneumol. 2010;36(1):124-33. DOI: http://dx.doi.org/10.1590/S1806-37132010000100017

19. Anandan C, Nurmatov U, van Schaik OC, Sheikh A. It the prevalence of asthma in decline? Systematic review of Epidemiological studies. Allergy. 2010;65(2):152-67. DOI: http://dx.doi.org/10.1111/j.1398-9995.2009.02244.x

20. Assis EV, Isidório UA, Feitosa ANA, Sousa MNA, Silveira GBM, Batista HMT, et al. Autonomic nervous system and allergic diseases: integrative literature review. Intern Arch Med. 2015;8(112):1-6. DOI: http://dx.doi.org/10.3823/1711

\section{Resumo}

Introdução: A asma é a doença crônica das vias aéreas que vem apresentando um aumento na sua prevalência entre os adolescentes nas últimas décadas. Os fatores relacionados com o seu desencadeamento são inúmeros, passando por fatores ambientais, genéticos, alimentares dentre outros.

Objetivo: Analisar a prevalência dos sintomas da asma e possíveis fatores de risco associados em adolescentes.

Método: Trata-se de um estudo transversal, descritivo e quantitativo realizado em 104 adolescentes de 13 e 14 anos, de ambos os sexos, de quatro instituições de ensino: três privadas e uma pública. Os participantes responderam a dois questionários: um sobre os fatores de risco para doenças alérgicas e o outro sobre os sintomas da asma (ISAAC módulo asma).

Resultados: Responderam ao questionário 104 adolescentes: 54,8\% meninas e $45,2 \%$ meninos. Os voluntários do sexo masculino apresentaram mais asma ativa $(64, \%)$ que as voluntárias $(20 \%)(p=0,01)$ e também tiveram mais asma diagnosticada $(34,4 \%)$ do que as voluntárias $(6,1 \%)(p=0,04)$, além de mais chiado no peito após exercício $(34,4 \% ; 12,1 \%)(p=0,03)$. Com relação à associação entre os sintomas e os fatores de riscos observou-se uma relação estatisticamente significante entre presença de sibilos e hospitalizações para as meninas de escolas públicas $(p=0,05)$.

Conclusão: Houve maior frequência de adolescentes do sexo masculino com asma ativa, asma diagnostica e sibilos após exercício físico. Por outro lado, as meninas da escola pública apresentaram um maior risco de hospitalização na presença de sibilos. Os demais fatores de riscos não apresentaram associações estatisticamente significantes com os sintomas da asma.

Palavras-chave: adolescente, disfunção autonômica, doença alérgica, epidemiologia, fatores de risco.

\footnotetext{
${ }^{\odot}$ The authors (2019), this article is distributed under the terms of the Creative Commons Attribution 4.0 International License (http:// creativecommons.org/licenses/by/4.0/), which permits unrestricted use, distribution, and reproduction in any medium, provided you give appropriate credit to the original author(s) and the source, provide a link to the Creative Commons license, and indicate if changes were made. The Creative Commons Public Domain Dedication waiver (http://creativecommons.org/publicdomain/zero/ $1.0 /)$ applies to the data made available in this article, unless otherwise stated.
} 